\title{
Biodiversity Loss in Latin American Coffee Landscapes: Review of the Evidence on Ants, Birds, and Trees
}

\author{
STACY M. PHILPOTT, ${ }^{*} \neq \ddagger \ddagger$ WAYNE J. ARENDT, $†$ INGE ARMBRECHT, $\ddagger$ PETER BICHIER,${ }^{*}$ \\ THOMAS V. DIESTCH, $§$ CALEB GORDON, ${ }^{* *}$ RUSSELL GREENBERG,${ }^{*}$ IVETTE PERFECTO, $\dagger$ \\ ROBERTO REYNOSO-SANTOS, $\ddagger \ddagger$ LORENA SOTO-PINTO, $§ \S$ CESAR TEJEDA-CRUZ, ${ }^{* * *}$ \\ GUADALUPE WILLIAMS-LINERA, ${ }^{* * *}$ JORGE VALENZUELA, ${ }^{* * *}$ AND JOSÉ MANUEL ZOLOTOFF $† \dagger \dagger$
}

*Smithsonian Migratory Bird Center, Washington, D.C. 20013, U.S.A.

†USDA Forest Service, International Institute of Tropical Forestry, San Juan 00773, Puerto Rico

‡Departamento de Biología, Universidad del Valle, Cali 25360, Colombia

$\S$ Center for Tropical Research, University of California, Los Angeles, CA 90095, U.S.A.

${ }^{* *}$ Department of Biology, Lake Forest College, Lake Forest, IL 60045, U.S.A.

††School of Natural Resources and Environment, University of Michigan, Ann Arbor, MI 48109, U.S.A.

‡¥Instituto Nacional de Investigaciones Forestales, Agrícolas, and Pecuarias Pacífico SUR, Ocozocoautla, Chiapas 29140, México

$\S \S E l$ Colegio de la Frontera Sur, San Cristóbal de las Casas, Chiapas 29200, México

***Instituto de Ecología, Xalapa, Veracruz 91070, México

†††Fundación Cocibolca, A.P. C-212 Managua, Nicaragua

\begin{abstract}
Studies have documented biodiversity losses due to intensification of coffee management (reduction in canopy richness and complexity). Nevertbeless, questions remain regarding relative sensitivity of different taxa, habitat specialists, and functional groups, and whether implications for biodiversity conservation vary across regions. We quantitatively reviewed data from ant, bird, and tree biodiversity studies in coffee agroecosystems to address the following questions: Does species richness decline with intensification or with individual vegetation characteristics? Are there significant losses of species richness in coffee-management systems compared with forests? Is species loss greater for forest species or for particular functional groups? and Are ants or birds more strongly affected by intensification? Across studies, ant and bird richness declined with management intensification and with changes in vegetation. Species richness of all ants and birds and of forest ant and bird species was lower in most coffee agroecosystems than in forests, but rustic coffee (grown under native forest canopies) had equal or greater ant and bird richness than nearby forests. Sun coffee (grown without canopy trees) sustained the highest species losses, and species loss of forest ant, bird, and tree species increased with management intensity. Losses of ant and bird species were similar, although losses of forest ants were more drastic in rustic coffee. Richness of migratory birds and of birds that forage across vegetation strata was less affected by intensification than richness of resident, canopy, and understory bird species. Rustic farms protected more species than other coffee systems, and loss of species depended greatly on babitat specialization and functional traits. We recommend that forest be protected, rustic coffee be promoted, and intensive coffee farms be restored by augmenting native tree density and richness and allowing growth of epiphytes. We also recommend that future research focus on potential trade-offs between biodiversity conservation and farmer liveliboods stemming from coffee production.
\end{abstract}

Keywords: agroecosystem, biodiversity, coffee production systems, meta-analysis, shade-grown coffee, site characteristic, sun-grown coffee

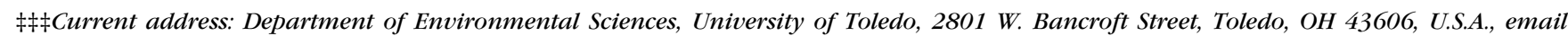
stacy.philpott@utoledo.edu

Paper submitted August 6, 2007; revised manuscript accepted April 3, 2008. 
Pérdida de Biodiversidad en Paisajes Cafetaleros en Latinoamérica: Revisión de la Evidencia en Hormigas, Aves y Árboles

Resumen: Diversos estudios han documentado las pérdidas de biodiversidad debido a la intensificación del manejo de café (disminución de la riqueza y complejidad del dosel). Sin embargo, persisten preguntas sobre la sensibilidad relativa de diferentes taxa, especialistas de hábitat y grupos funcionales, y sí las implicaciones para la conservación de la biodiversidad varían entre regiones. Revisamos cuantitativamente los datos de estudios de biodiversidad de hormigas, aves y árboles en agroecosistemas de café para abordar las siguientes preguntas: ¿La riqueza de especies declina con la intensificación o con las características individuales de la vegetación? ¿Hay pérdidas significativas de riqueza de especies en los sistemas cafetaleros en comparación con los bosques? ¿Es mayor la pérdida en especies de bosque o en grupos funcionales particulares? y ¿Las aves o las hormigas son más afectadas por la intensificación? En los estudios revisados, la riqueza de hormigas y aves declinó con la intensificación del manejo y con los cambios de vegetación. La riqueza de especies de todas las hormigas y aves y la de especies de bormigas y aves de bosque fue menor en la mayoría de los agroecosistemas cafetaleros que en los bosques, pero el café rústico (cultivado bajo dosel de bosque nativo) sustentó la mayor pérdida de especies, y la pérdida de especies de hormigas, aves y árboles de bosque aumentó con la intensificación del manejo. Las pérdidas de especies de bormigas y aves fueron similares, aunque las pérdidas de hormigas de bosque fueron más drásticas en el café rústico. La riqueza de especies de aves migratorias y de aves que forrajean en varios estratos de vegetación fueron menos afectadas por la intensificación que las especies residentes de dosel y de sotobosque. Las fincas rústicas protegieron más especies que otros sistemas cafetaleros, y la pérdida de especies dependió mayormente de la especialización de hábitaty de los atributos funcionales. Recomendamos que el bosque sea protegido, se promueva el café rústico y se restauren las fincas intensivas mediante el incremento de la densidad y riqueza de árboles nativos y permitiendo el crecimiento de epífitas. También recomendamos que las futuras investigaciones enfoquen las compensaciones potenciales entre la conservación de la biodiversidad y la forma de vida de los campesinos que producen café.

Palabras Clave: agroecosistema, biodiversidad, café con sombra, café sin sombra, característico del sitio, meta análisis, producción de café

\section{Introduction}

Agricultural systems make essential contributions toward conservation (Vandermeer \& Perfecto 2007). Vegetatively complex agroecosystems that incorporate tall, diverse, and dense canopies can maintain levels of biodiversity similar to forests (Moguel \& Toledo 1999). Furthermore, a high-quality agricultural matrix can facilitate dispersal of animals among forest fragments (Vandermeer \& Carvajal 2001; Steffan-Dewenter 2002) and maintain metapopulation dynamics and long-term survival of forest species (Vandermeer \& Carvajal 2001; Perfecto \& Vandermeer 2002). In addition, diverse agroecosystems can provide alternative and more sustainable livelihoods for families, reducing the need to cut forests (Blackman et al. 2003; Gordon et al. 2007) and economic risks (Toledo \& Moguel 1996).

Coffee agroecosystems have received substantial attention for their apparent capacity to protect biodiversity. Coffee agroecosystems preserve habitat and resources for associated biodiversity, especially in areas with little forest (Perfecto et al. 1996; Moguel \& Toledo 1999; Wunderle 1999). Intensification of coffee management, however, results in biodiversity loss. Coffee was traditionally cultivated under diverse, dense shade canopies, but modern cultivation methods are characterized by reduction of shade tree density and diversity, removal of epiphytes, and agrochemical use (Moguel \& Toledo 1999). Across production systems, rustic agroforests, in which crops grow under a native forest canopy, are the most biodiverse (Perfecto et al. 1996; Greenberg et al. 1997; Klein et al. 2002; Armbrecht et al. 2005; Gordon et al. 2007). Nonetheless, study results do not always show significant declines in species richness with intensification of coffee management (e.g., Ricketts et al. 2001; Ramos et al. 2002; Pinkus-Rendon et al. 2006).

There are several reasons why the results of these studies differ. Taxonomic groups may differ in responses to intensification, such that only certain groups are sensitive to habitat change. Ecological responses of animals to coffee intensification may differ with the particular plant species found in a region. Finally, shade-coffee habitat in different studies may not represent a single habitat type. Those with experience working in several coffeegrowing regions, for example, recognize that typical shade-coffee systems in Costa Rica (where shade and sun coffee may not differ in biodiversity value [e.g. Ricketts et al. 2001]) are qualitatively different than typical shadecoffee systems in Mexico (where there are far more individuals and species of trees). Nevertheless, those without direct experience may have trouble distinguishing subtleties without quantitative data. Thus, differences in 
interpretation of study results have led to discussion over whether shade coffee is an appropriate habitat for biodiversity conservation.

Although there are over 100 papers on coffee management and biodiversity, no quantitative synthesis exists to facilitate analyzing the management recommendations of previous studies. Many studies compare bird, tree, or arthropod biodiversity in coffee agroecosystems that differ in management intensity or compare biodiversity in coffee agroecosystems with forests or other agricultural habitats, but few have examined multiple taxonomic groups (but see Perfecto et al. 2003; Pineda et al. 2005; Gordon et al. 2007). Furthermore, few studies publish data on vegetation characteristics (e.g., tree species richness, canopy cover) associated with coffee intensification and potential correlations with species richness (Mas \& Dietsch 2003). Although a clear continuum of coffee-management systems exists, researchers generally develop individualized characterizations of shademanagement practices in their study sites. For instance, the most-cited coffee biodiversity studies include more than 25 names to describe coffee-management systems, making cross-study comparisons of similar studies in different regions challenging. Even if authors were to use standardized names, such as those suggested by Moguel and Toledo (1999), confirming accuracy of classifications without relevant vegetation data would be difficult.

A few recent reviews summarize results for certain taxa (ants: Philpott \& Armbrecht 2006; birds, Komar 2006). Yet, these papers do not take advantage of quantitative methods to compare studies or examine patterns of species loss, which makes the conclusions drawn from them somewhat suspect. Qualitative reviews or votecounting techniques cannot take into account variable methodologies or sample sizes and thus cannot effectively give those studies with larger samples more weight (Arnqvist \& Wooster 1995). Were authors to cooperate and provide standardized assessments of vegetation and site characteristics in their study sites, methods standardizing effect sizes across multiple studies could describe emergent patterns in studies of biodiversity in coffee agroecosystems.

We standardized site types for a set of coffee biodiversity studies and used various quantitative methods to examine biodiversity losses across a range of coffeemanagement systems. Primarily, we examined work on 3 taxa: birds, ants, and trees. We sought to address the following questions: Does species richness decline with coffee-management intensification or with individual vegetation characteristics? Are there significant losses of species richness in coffee-management systems compared with forests? Is species loss greater for forest species or for particular functional groups? and Are ants or birds more strongly affected by management intensification? On the basis of our findings, we provide specific recommendations for biodiversity conservation within coffee agroecosystems.

\section{Methods}

\section{Data Collection}

We collected data from published sources found on the ISI Web of Science by inputting all combinations of the keywords ant ${ }^{*}$, bird $^{*}$, tree $^{*}$, avian, diversity, biodiversity, and coffee and from unpublished work. We limited the scope of the studies we examined to the Neotropics (excluding the Caribbean) and contacted study authors for their complete data sets. We collected 6 data sets for ants, 12 for birds, and 9 for trees, of which 15 represented 4 coffee regions in Mexico and 1 each in Peru, Colombia, Guatemala, and Nicaragua. Full citations of each study included and site descriptions (including elevation, climate, topography, and land use) are available (Philpott 2007).

Sampling technique, timing, plot size, and sampling frequency differed among studies. Ants were sampled with visual counts, pitfall traps, tuna baits, litter traps, and by breaking open dry twigs on plants and on the ground. Trees were sampled by counting and identifying all trees per plot to species or morphospecies. For birds, we considered data only from studies in which 10-min, 25-m-radius point counts were used. Sampling method, number of replicates, sample area, and habitat types sampled for each study we considered are available (Philpott 2007).

\section{Site Classifications}

Researchers who contributed data classified study sites into 1 of 7 habitats ( 2 forest types, primary and secondary; 5 coffee systems, rustic, traditional polyculture, commercial polyculture, shade monoculture, and sun) following criteria we devised (Table 1) on the basis of coffeemanagement systems described by Moguel and Toledo (1999). We asked authors to classify sites according to quantitative specifications for vegetation variables and for management techniques (Table 1). Because chemical use is difficult to quantify and somewhat independent of shade management, we did not include this in our classification. Complete site descriptions and categories into which they were classified are available (Philpott 2007).

\section{Vegetation Characteristics of Study Sites}

We combined vegetation data from individual studies (24 variables) into 10 summary variables that described site characteristics: elevation, tree richness, tree density, canopy cover, canopy height, canopy structure, coffee density, understory height, epiphyte abundance, 


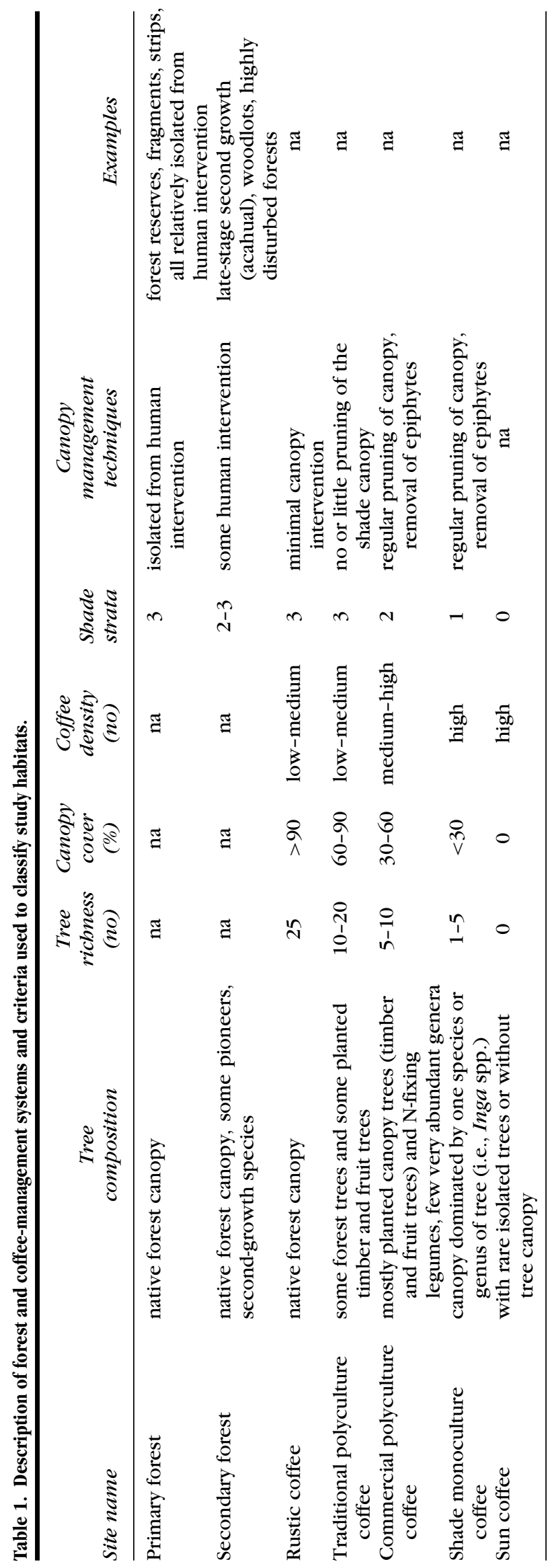

and ground cover. Elevation, tree richness, and percent canopy cover were assessed with the same measurement in each study. We standardized tree density per hectare by converting density per plot area to density per hectare. For similar variables measured in 2 or more ways, we combined data. For example, canopy height encompassed mean tree height, highest canopy height, lowest canopy height, and percent emergent trees. Canopy structure encompassed canopy depth, structural depth, and number of shade strata. Coffee density encompassed percent plot cover with coffee plants and number of coffee plants per hectare. Understory height encompassed mean coffee height, mean understory height, highest coffee height, and lowest coffee height. Epiphyte abundance included percentage of trees with epiphytes, percentage of trunk covered with epiphytes, number of epiphytes per hectare, and an index of epiphyte abundance. Ground cover included percent cover from herbaceous plants and percent leaf-litter cover.

To calculate summary variable values, we divided all values for a given variable by the highest observed value creating a scale from 0 (low values) to 1 (high values) and then took the mean of variables in the same category. Because coffee density is proportional to management intensity, in contrast to other variables, we subtracted the coffee density values from 1 . We used these summary variables to create a management-intensity index (MI) (Mas \& Dietsch 2003). We added all values for the summary variables from each plot in each study, divided this sum by the total number of variables measured in a plot, and subtracted the quotient from 1 to obtain a value from 0 to 1 , with 1 being the most intensive management. We calculated the MI for each coffee management and forest type in each study by averaging across all plots in that habitat type. We tested for differences in vegetation characteristics among the 7 site types with univariate analysis of variance (ANOVA). Tests were conducted in part to confirm that the categories (Table 1) did, in fact, create a range of distinctive management types.

\section{Influence of Vegetation and Overall Management Intensity on Species Richness}

We assessed the influence of individual vegetation factors and the MI on ant or bird richness with a meta-analysis. Although it may suffice to show that richness declines with increases in MI from a scientific standpoint, farmers' management practices modify individual vegetation factors. Furthermore, few researchers present data on relationships between ant and bird diversity and vegetation characteristics. Thus, we analyzed both individual factors and the MI. First, using the raw data from each study, we carried out simple linear regressions with observed ant or bird richness in a plot as the dependent variable and the value of each of the 10 summary variables in that plot as the independent variable. Thus, we ran a maximum of 
11 regressions for each study for each taxa (ants or birds) for which the number of vegetation variables collected in that study (plus the MI) determined the total number of regressions conducted. With the correlation coefficients $(r)$ generated and the number of plots included in each regression $(n)$, we calculated Fisher's (1928) $z$ transform in Meta-Win (version 2.0) as

$$
z=\frac{1}{2} \ln \left(\frac{1+r}{1-r}\right)
$$

and the asymptotic variance of $z$ as

$$
v_{z}=\frac{1}{n-3}
$$

(Sokal \& Rohlf 1995). Thus, we calculated a $z$ and $v_{z}$ value for each pair of variables (e.g., bird richness vs. canopy cover; bird richness vs. tree density) measured in each study. We then conducted a series of random-effects weighted summary analyses with $z$ values as effect sizes and $v_{z}$ as the variance to calculate mean $z$ and $95 \%$ confidence intervals (CIs) for each vegetation variable and taxa combination. A negative value of $z$ thus reflects a negative correlation, a positive value of $z$ reflects a positive correlation, and a zero value of $z$ represents no correlation between a vegetation characteristic (or the MI) and species richness of ants or birds. We considered $z$ values to demonstrate significant positive or negative relationships between ant and bird diversity and vegetation characteristics if $95 \%$ CIs did not overlap zero (Cooper \& Hedges 1994). For comparisons where $n \geq 10$, we used bootstrapped $95 \%$ CIs, but where $n<10$, we used parametric $95 \%$ CIs that provide a more conservative error estimate (Bancroft et al. 2007).

For significant $z$ values, we looked for the potential of publication bias in the meta-analysis with statistics available in Meta-Win. First, we calculated Spearman's rankorder correlation, $r_{s}$, a statistic that describes the relationship between the effect size (in our case $z$ ) and the sample size of the analysis (no. of plots in each study) (Begg \& Mazumdar 1994). Because sample size should correlate with variance of the effect size, we used $v_{z}$ in our analysis instead of the number of plots in each study. A significant correlation of $r_{s}$ (i.e., $p<0.05$ ) demonstrated significant publication bias, whereby, for example, larger effect sizes are more likely to be published than smaller effect sizes. We also calculated Rosenthal's fail-safe number with Meta-Win. This value yields the number of additional studies with a mean effect size of zero, $N_{R}$, needed to eliminate the significance of a significant effect (Rosenthal 1979). If the fail-safe number is larger than a critical value of $5 n+10$, where $n$ is the number of studies, then publication bias may be safely ignored (i.e., the results are robust regardless of publication bias [e.g., Rosenberg 2005]).

\section{Species Richness and Standardization of Species Change}

We examined species loss of all species and of forest species (defined as those present in forest samples) in different coffee-management systems relative to nearby forests. Using the raw data provided, we generated separate species rarefaction curves for all species and for forest species for each habitat type in each study with Mao Tao output from Estimates (version 7.5; Colwell 2005). We used values of rarefied richness to standardize for differences in sampling effort across different studies and habitat types (Gotelli \& Colwell 2001). We rarefied species richness to the lowest total number of individuals (or occurrences) observed across studies ( 77 bird individuals and 69 ant occurrences; 29 bird individuals and 32 ant occurrences for forest species). Rarefied richness values for all studies, habitats, and taxa are available (Philpott 2007).

We compared richness in each coffee system relative to forests with a standardized measure of species change. We combined primary and secondary forest together as forest samples. In most cases, only 1 of the 2 forest types was sampled. Standardized species change was calculated as

$$
\frac{\sum_{i=1}^{N_{j}} \frac{S_{j c}-S_{j f}}{S_{j c}+S_{j f}}}{N_{j}},
$$

where $N$ is the total number of studies, $j$, and $S$ is the rarefied richness in a particular coffee-management system, $c$, or forest, $f$, habitat (Gray et al. 2007). A negative value thus represents lower species richness in coffee compared with forests and a positive value indicates a net species gain relative to forest. This metric thus shows both the direction and magnitude of change in species richness.

We calculated standardized species change for each pair of sites (e.g., forest vs. commercial polyculture; forest vs. shade monoculture) in each study. We calculated standardized species change for all ants, all birds, forest ants, and forest birds separately. The standardized values of species change for pairs of sites in individual studies were then used as replicates in subsequent analyses. To examine the significance of species change for each comparison (e.g., forest vs. commercial polyculture), taxa (birds or ants), and species type (all or forest species), we took the mean across all studies and calculated bootstrapped $95 \%$ CIs with Meta-Win. We conducted an unweighted summary analysis with standardized species change as the effect size metric, inputting a column of $1 \mathrm{~s}$ for the variance, and selected the randomization test option to calculate CIs around the mean effect sizes for each coffee-management system. We considered species loss (or gain) significant if bootstrapped 95\% CIs 
did not overlap zero (Cooper \& Hedges 1994; Langellotto \& Denno 2004).

We used simple linear regressions to examine whether standardized species change for all ants or birds, or for forest ants or birds change varied with the MI. Each point in the regression referred to the standardized specieschange values for one habitat pair (e.g., forest vs. commercial polyculture) in one study and the mean MI of that coffee type in the same study (e.g. commercial polyculture).

We compared the relative effect of coffee-management intensification on ants and birds by comparing standardized species change for birds and ants both for all species and for forest species. We used a series of categorical summary analyses (analogous to ANOVA) in Meta-Win with standardized species change as the effect size metric, a column of $1 \mathrm{~s}$ for the variance, and the random test option. For each analysis, we included standardized species loss for both ants and birds and replicates of only 1 habitat comparison (e.g., forest vs. commercial polyculture). We ran 2 analyses for each habitat comparison, 1 with data for all birds and ants and the other with forest birds and ants.

We also examined patterns of species loss as a function of 2 bird traits, primary foraging strata and migratory status. Data on bird foraging strata were extracted from Stotz et al. (1996), Sabo and Holmes (1983), and Jones and Hansen (2006). We classified birds into 3 categories: canopy birds that forage in the upper or mid canopy, understory birds that forage in the understory or on the ground, and birds that forage across all vegetation strata. We classified birds as either migrants (including both Nearctic-Neotropical and Austral migrants) or residents. Richness was rarefied to 20 individuals for migrant and resident birds and to 15 individuals for foraging strata. We examined standardized species change for the different bird groups (canopy, understory, both strata, migrants, and residents) with the same methodology as described for all birds. For each bird group we calculated standardized species change for each pair of habitats in a study and then used values from individual studies as replicates to calculate mean standardized species change and 95\% CIs for each coffee type and bird group. We then used simple linear regressions to examine whether standardized species change of each bird group varied with the MI as for all birds.

\section{Results}

The vegetation characteristics and management indices calculated for each habitat reflected a clear gradient of management intensification (Table 2). Management intensity was lowest in primary forest and rustic coffee, higher in secondary forest, traditional polyculture,

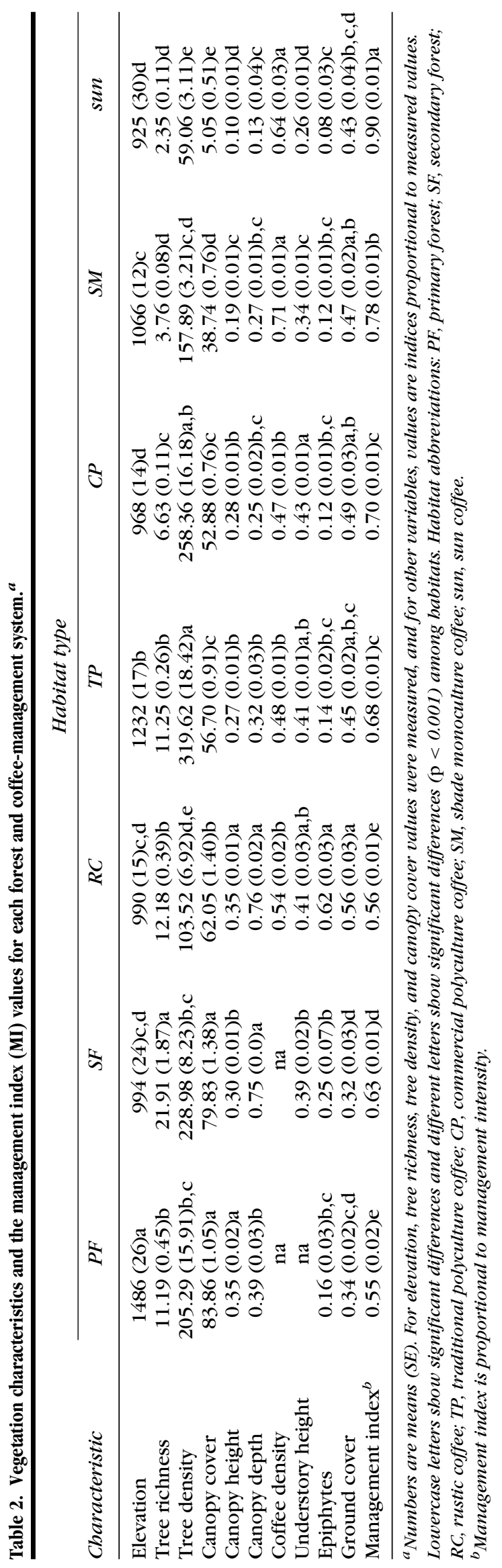


commercial polyculture, shade monoculture, and highest in sun coffee. All vegetation variables differed significantly among habitat types. Decreases in tree richness, canopy cover, and canopy height, and increases in coffee density generally followed the management intensification gradient (Table 2). Bird richness declined with increases in management intensity, and ant and bird richness was negatively correlated with losses in several vegetation characteristics (Fig. 1). For vegetation variables that significantly correlated with bird richness (canopy cover, canopy depth, canopy height, coffee density, epiphyte index, tree richness, tree density, and MI), only the MI showed a significant publication bias $\left(r_{s}=0.65, p=\right.$ $0.022)$. For MI the calculated Rosenthal's fail save number (871.8) was far above the critical value (70), showing that a large number of additional studies with an effect size of zero would need be included to remove the significance of the MI on bird richness and rejecting the possibility of publication bias. Elevation and tree richness correlated with ant richness but neither elevation $\left(r_{s}=0, p=1.0\right)$ nor tree richness $\left(r_{s}=-0.316, p=0.684\right)$ showed significant publication bias.

Loss of ant and bird species was significant for most coffee-management systems (Fig. 2). On the basis of $95 \%$ CIs, there was significant loss of ant species in all coffee systems except rustic coffee. There were more bird species in rustic coffee relative to forests, fewer species in traditional polyculture, commercial polyculture, and sun coffee, but no loss or gain in shade monoculture. Patterns of loss of forest species differed for all species. There was significant species loss of forest ants and forest birds in each coffee-management type compared with forests. Species loss of ants did not correlate with MI (Figs. 3a \& 3b). Likewise, species loss (or gain) of birds did not correlate with MI, but forest bird species loss was greater in more intensive coffee sites (Figs. 3c \& 3d).

There were few significant differences in species loss between birds and ants. There was a significantly higher species loss, relative to forest, for forest ants in rustic coffee than for forest birds $(Q=0.049$, df $=5, p=$ $0.025)$. There were no significant differences in standardized species loss for all ants and birds in any habitat type $(p>0.05)$ and no other significant differences in species loss for forest ants and birds $(p>0.05)$.

Patterns of species loss for canopy and understory birds differed from birds that forage in both strata and between migrant and resident birds. There were significant species gains of bird species that forage in both strata in rustic coffee compared with forests, but no species change in other coffee systems (Fig. 4a). In contrast, there were fewer canopy and understory birds in all coffee systems compared with nearby forests, with the exception of understory birds in commercial polyculture (Fig. 4a). There was significant loss of migrant species relative to forests

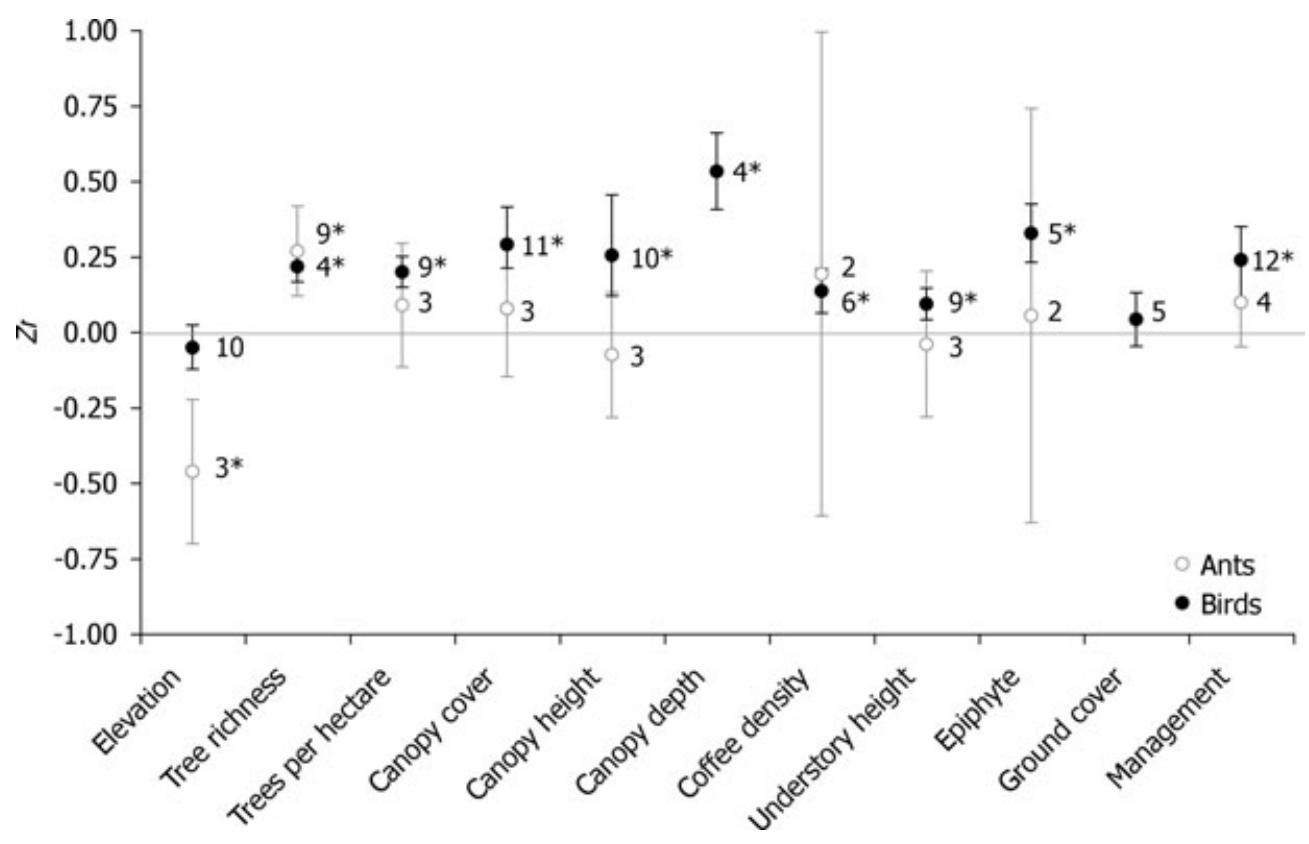

Figure 1. Influences of vegetation site characteristics and management index (management) on richness of ant and bird species (Z, Fisher's Z; r, correlation coefficient). Management intensity increases with bigher management index. See text for calculation of effect size. Numbers to right of symbols show sample sizes for number of studies included. Error bars for points with $\mathrm{n} \geq 10$ are bootstrapped 95\% CIs, and those points with $\mathrm{n}$ $<10$ are parametric 95\% CIs. Error bars not overlapping zero show significant positive or negative correlations (also marked with asterisks). 


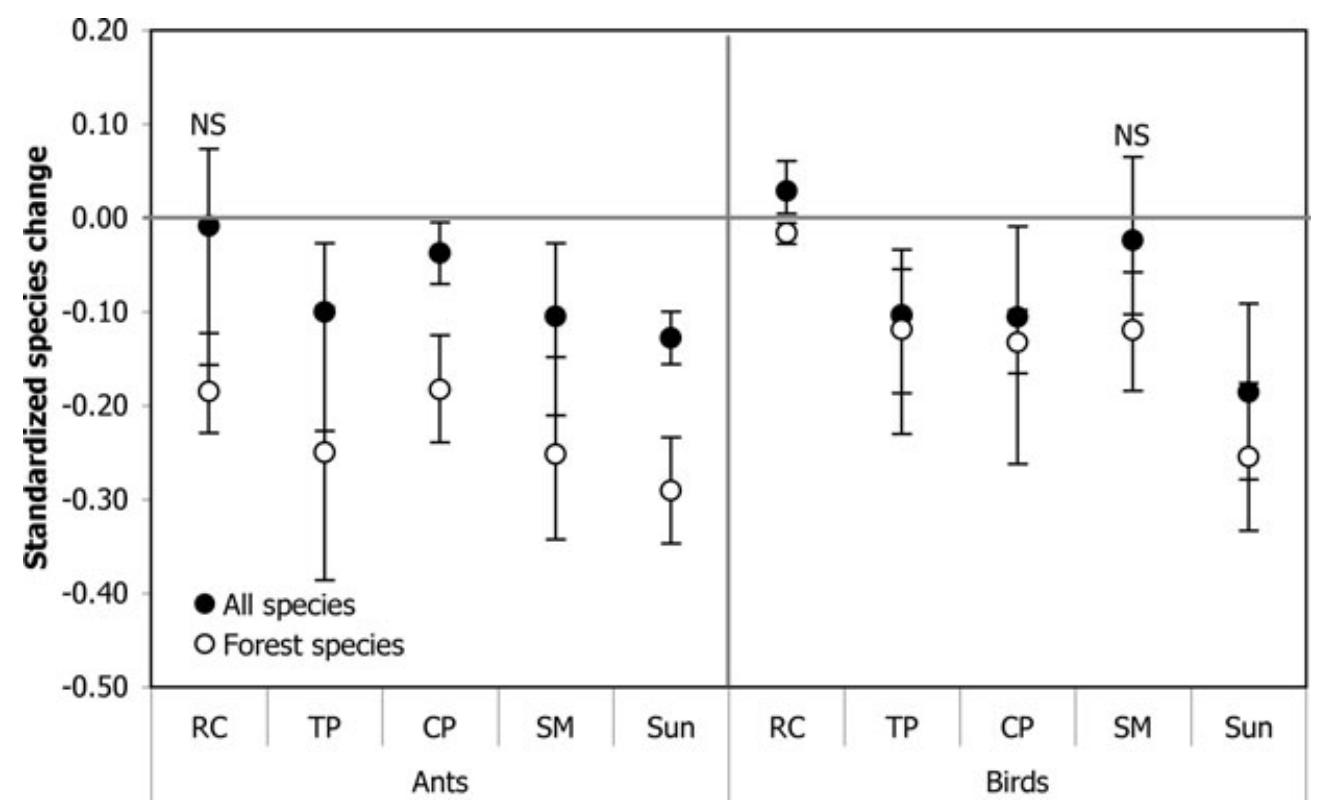

Figure 2. Standardized change in species richness for ants and birds in coffee sites compared with nearby forests. See text for information about calculation of standardized species change. Error bars are bootstrapped $95 \%$ CIs. Points below zero show species loss relative to forests, and points above zero show significant increases in species richness compared with forests. Error bars that do not overlap zero show significantly bigher or lower richness in coffee habitats compared with forests (NS, points not significantly different from zero). Habitat abbreviations: PF, primary forest; SF, secondary forest; RC, rustic coffee; TP, traditional polyculture coffee; CP, commercial polyculture coffee; SM, shade monoculture coffee; Sun, sun coffee.

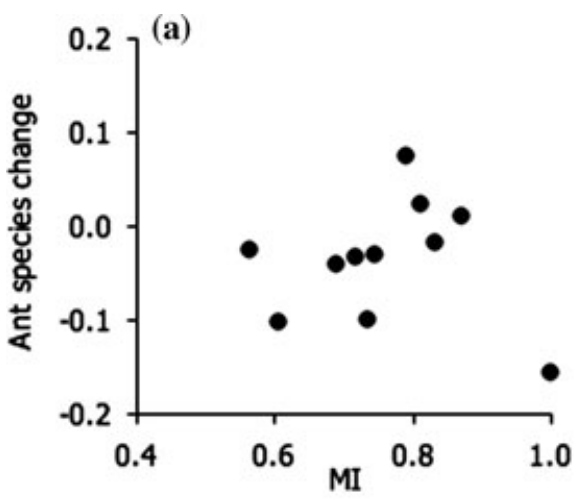

(c)

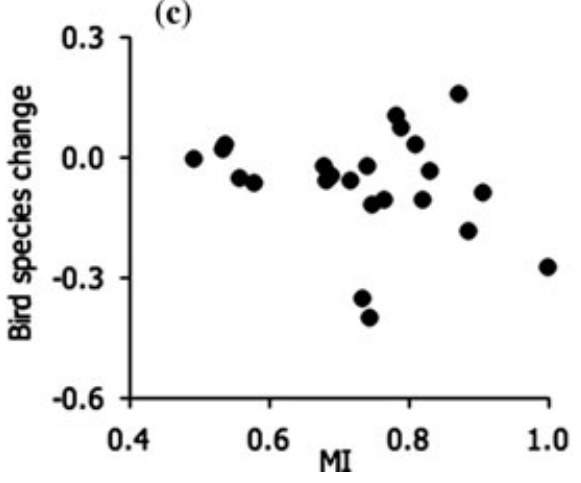

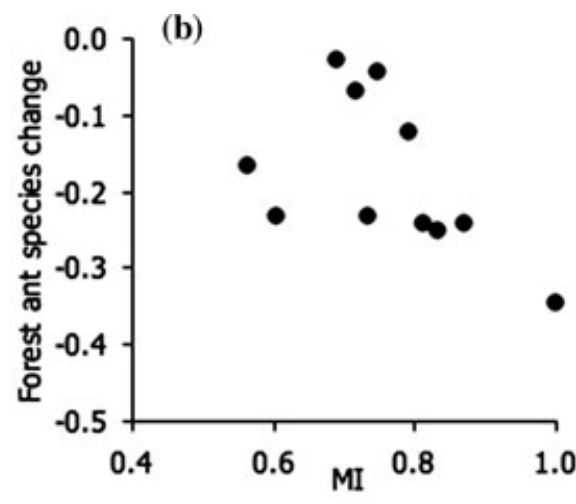

(d)

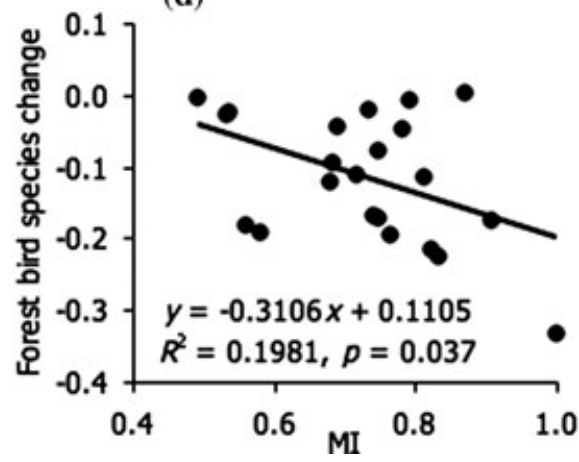

Figure 3. Relationships between management intensity (measured as a management index [MI]; O, low; 1 bigh) and standardized species richness change of $(a, b)$ ants and $(c, d)$ birds for $(a, c)$ all species and for $(b, d)$ forest species. See text for information about calculation of standardized species change. Each point represents a single babitat type in one study (ants $\mathrm{n}=11$, birds $\mathrm{n}=23$ ). Negative change values represent a species loss in coffee relative to forests and positive values represent $a$ net gain in species richness. The $\mathrm{p}$ value is for simple linear regression. 

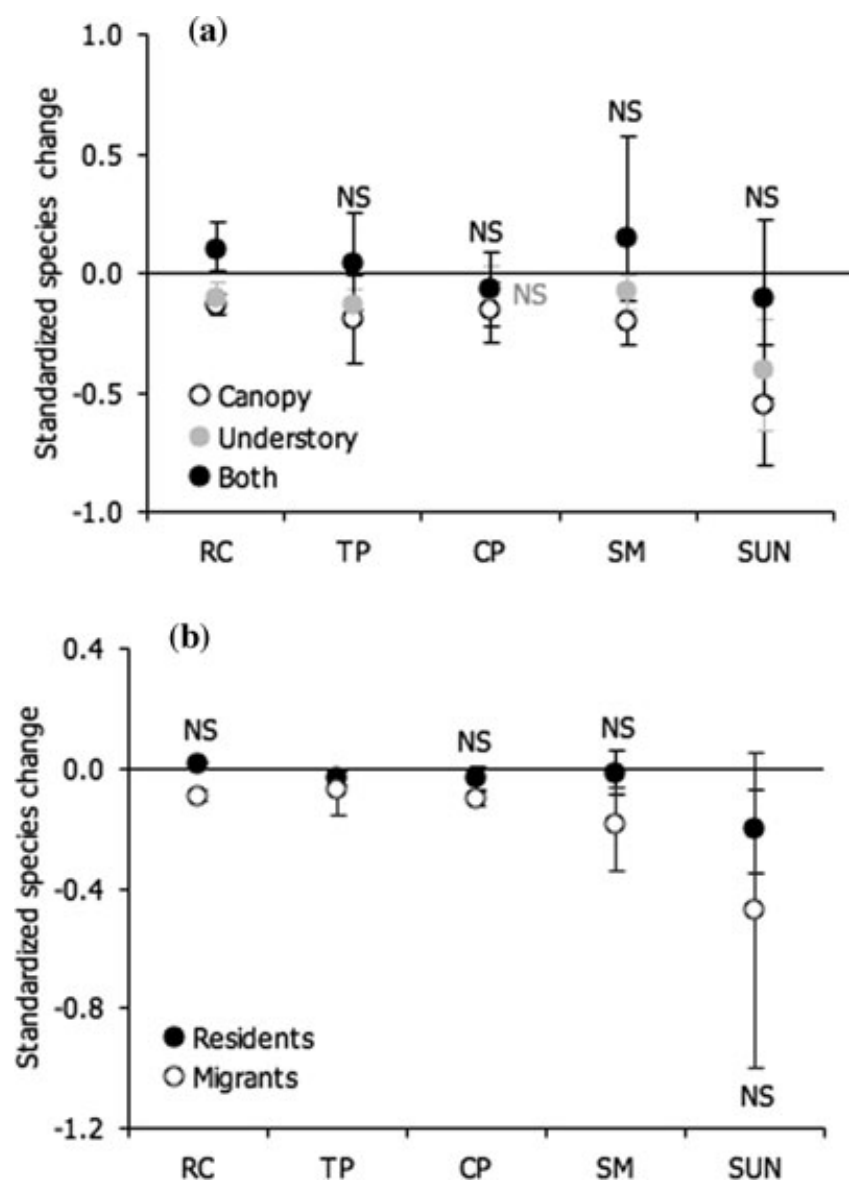

Figure 4. Standardized change in species richness of birds belonging to (a) different foraging strata groups and (b) different migrant status in coffee sites compared with nearby forests. Error bars show bootstrapped 95\% CIs. Points below the zero line show species loss, and points above the zero line show significant species gain compared with forests. Error bars that do not overlap zero show significant changes in richness (NS, points that are not significantly different from zero). Habitat abbreviations: PF, primary forest; SF, secondary forest; RC, rustic coffee; TP, traditional polyculture coffee; $C P$, commercial polyculture coffee; SM, shade monoculture coffee; SUN, sun coffee.

in all coffee habitats except for sun coffee, yet only significant resident species losses for traditional polyculture and sun-coffee systems (Fig. 4b).

Relationships between standardized species change and MI also differed on the basis of bird foraging strata and migratory status. There were significant increases in species loss for canopy and understory birds with increases in MI, but no increase in species losses with MI for birds that forage in both vegetation strata (Figs. 5a-c). Species loss of migrants tended to increase with the MI, but this was not statistically significant (Fig. 5d). Species loss of resident birds increased significantly with MI (Fig. 5e).

\section{Discussion}

In our study diversity of trees, birds, and ants declined with management intensification, rustic coffee farms supported higher levels of biodiversity than other moreintensive systems, and several vegetation characteristics were related to species losses. Tree richness was similar to forests in sites with more complex shade, but there were significantly fewer tree species in commercial polyculture, shade monoculture, and sun-coffee systems than in forests or coffee farms with greater vegetation complexity. Although this may seem an obvious result, few researchers have examined declines in tree species richness with coffee intensification.

Ant and bird richness declined significantly with management intensification, and several vegetation factors were correlated with these losses. Species loss of ants did not correlate with the MI-ant species were lost in all coffee systems. Species loss of all ants and of forest ants did not vary with intensification, indicating that all coffee systems (except rustic coffee) supported fewer ant species than forests.

Losses of bird richness and forest bird richness were significant in all management systems except for rustic and shade monoculture systems. There was a significant gain of bird species in rustic coffee compared with forests, corroborating similar findings (e.g., Greenberg et al. 1997). The lack of species change in shade monoculture can be attributed to very high richness in 2 of 3 studies conducted in Veracruz, Mexico (Gordon et al. 2007; Tejeda-Cruz \& Gordon 2008). High bird species richness in these sites may have occurred because the single-species (Inga) canopy was fairly tall and dense during sampling, which created a vegetation structure similar to many commercial polycultures. Furthermore, Inga trees provide seasonally abundant resources that attract birds, especially when trees are in flower (Johnson 2000), and this may have influenced bird abundance and richness.

Loss of forest ant species was significantly higher than loss of forest bird species in rustic coffee, which means forest ant species may be more sensitive to initial habitat changes than birds. Yet, there were no other significant differences in species losses between birds and ants in other coffee systems, contrary to other studies (Perfecto et al. 2003). Standardized species change of forest birds significantly correlated with the management index, indicating that species loss becomes greater as coffee systems are intensified.

Migrant and resident bird species were affected differently by management intensification, and species loss 

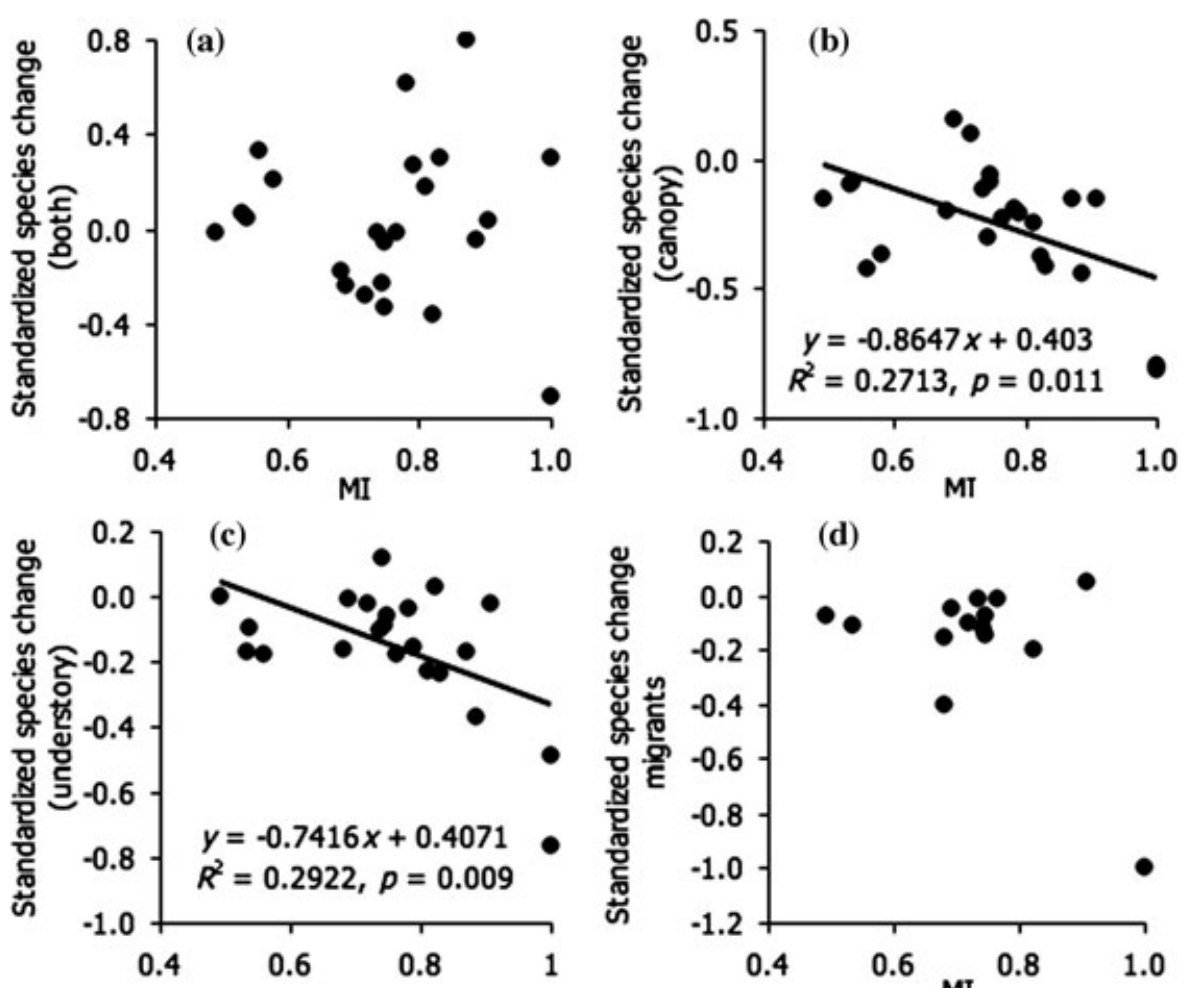

(e)
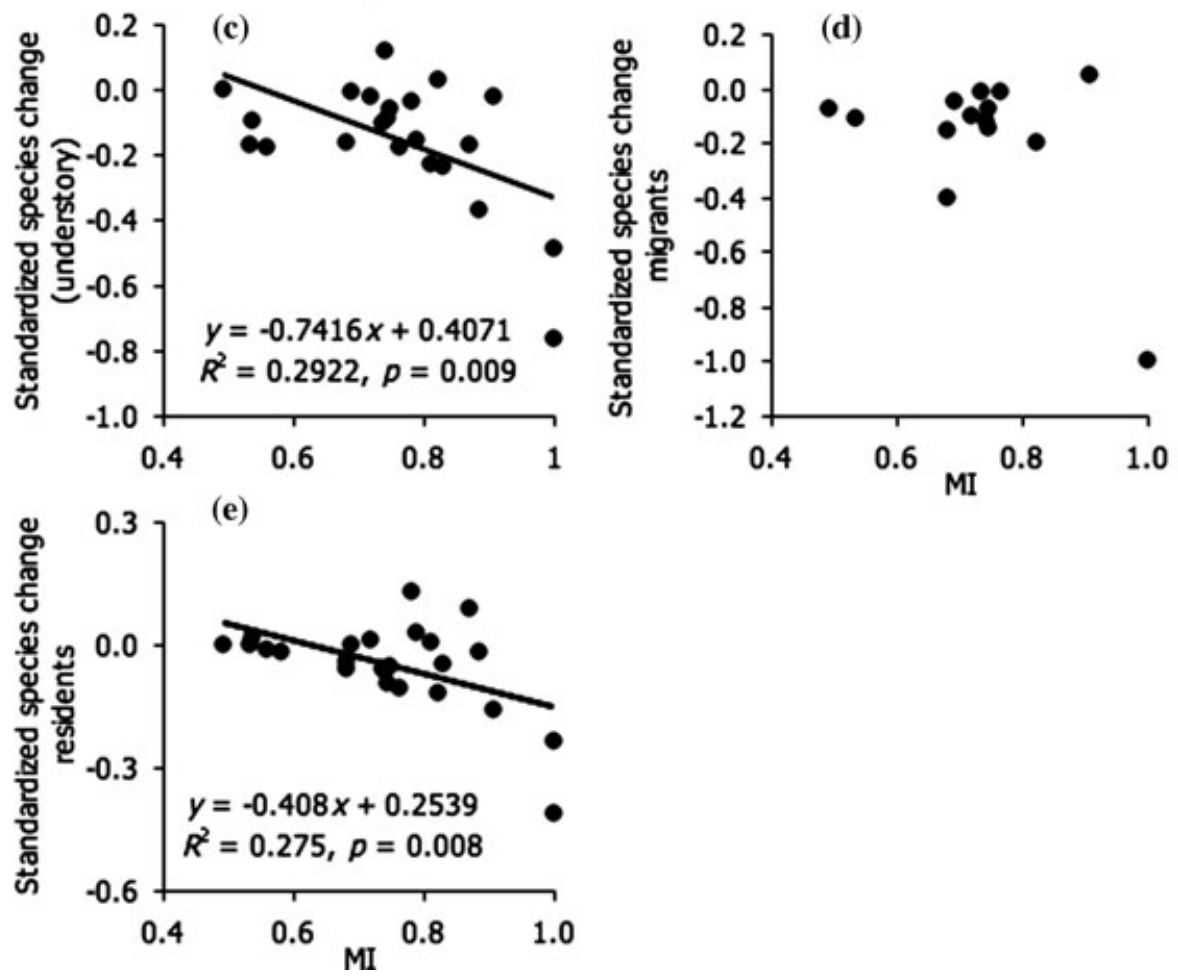

Figure 5. Relationships between management intensity (measured as a management index [MI]; O, low; 1 high) and standardized species richness change for birds that forage in (a) both understory and canopy, (b) canopy, (c) understory and for (d) migrant and (e) resident birds. Negative change values represent a species loss in coffee relative to forests and positive values represent a net gain. Each point represents a single babitat type in one study. The p values are for simple linear regressions. also differed depending on bird foraging strata. Species richness of resident birds tended to decline with management intensification, and species loss increased with management intensification. In contrast, migrant richness did not decline with management intensity, but there were significant losses in species richness of migrants in most coffee systems compared with forests. Species richness of canopy and understory birds was lost in all coffee systems, but richness of birds that forage in both strata was unaffected by habitat change or management intensity. These results partially corroborate findings that understory bird richness declines with intensification of coffee management, whereas the species richness of canopy and variable-strata foragers increases (Tejeda-Cruz \& Sutherland 2004). Thus, bird responses to intensification of coffee management depended on certain functional traits. Additional analyses of bird-foraging strategy and feeding guilds and of functional groups of ants and trees could provide further knowledge on the effects of coffee inten- sification on species assemblages and ecosystem function.

Most site characteristics varied with management system, but vegetation characteristics important for predicting animal species richness differed between ants and birds. Generally, tree richness, canopy cover, and canopy height declined with management intensification and coffee density increased. Tree richness was an important predictor of both bird and ant richness. Elevation correlated with ant richness. In addition, tree density, canopy cover, tree heights, canopy depth, coffee density, and understory height were important to birds. Overall MI also correlated with declines in bird richness. Sample sizes for comparisons, especially for ant richness, were very low; thus, for ants in particular, additional studies are needed to better assess the impacts of vegetation characteristics.

On the basis of our results, we propose several management recommendations to policy makers, extension agents, and farmers. Foremost, remaining forest patches 
should be protected because in most cases they maintain more species and more forest species than coffee agroecosystems. Species are lost as forest is converted to coffee, regardless of management intensity. Nevertheless, shade-coffee systems differ quantitatively. Rustic-coffee systems protect a greater diversity of ants, birds, and trees than other shade-coffee systems. Sun-coffee systems generally harbor fewer species, and fewer forest species of ants, birds, and trees than shade-coffee systems. Thus, from the standpoint of biodiversity preservation, rustic coffee should be promoted, but not at the expense of remaining forest patches (Rappole et al. 2003). These findings support the practice used by shade-coffeecertification organizations of certifying coffee grown on farms with higher vegetative complexity, shade cover, and greater tree height and diversity. Conservation efforts should also focus on restoring shade monoculture and sun-coffee farms to diverse, multistrata shade canopies to provide higher-quality habitat for biodiversity, especially for forest species. To promote biodiversity tree species richness should be augmented with native forest tree species, tree growth, and epiphyte establishment and pruning should be limited. Although rustic-coffee farms have high forest tree diversity, management at ground level may inhibit regeneration. Thus, active management of tree diversity may be necessary. This is another argument for protecting forest fragments as seed sources for surrounding habitats.

These recommendations must be assessed keeping in mind how shade management influences coffee production and farmer livelihoods. Changes in shade management could result in complex changes to agroecosystems. Farmers may view management promoting diverse multistrata canopies skeptically if they are perceived to increase fungal diseases, pest problems, and weeds. There is little evidence, however, that diverse canopy cover increases such problems. Likewise, the literature describing relationships between canopy cover and yield is contradictory; in some cases, highest yields are observed at intermediate levels of canopy cover (Soto-Pinto et al. 2000). Low production in rustic-coffee systems may result from a lack of attention to crops. Thus, production might be increased without removing vegetation, and additional techniques, such as composting and soil enrichment, could improve production on farms. Other management techniques could be altered to increase biodiversity without affecting yields. For example, epiphyte removal is common, but it is unlikely that epiphyte removal increases production. Leaving epiphytes may greatly increase bird diversity (Cruz-Angon \& Greenberg 2005). Furthermore, there is no relationship between shade tree diversity, per se, and yield (Romero-Alverado et al. 2002), but increasing tree richness does increase richness of bird species. Shade cover may also promote increased pest control and pollination services (Klein et al. 2002; Perfecto et al. 2004). More research is needed on interactions between biodiversity conservation, shade management, farmer livelihoods, and coffee yields to determine whether perceived trade-offs between ecological and economic goals for coffee exist as for other agroforest crops (Steffan-Dewenter et al. 2007).

If rustic coffee does negatively correlate with farmer benefits, then consumers or other funding mechanisms should pay premiums to farmers who grow rustic coffee so biodiversity protection will be economically sustainable. The results of one analysis indicate that when such premiums are paid, diverse multistrata farms can be as profitable as more intensively managed farms (Gordon et al. 2007). Alternatively, specific payment for ecosystem services (PES) programs, such as "Programa Pro-Árbol" of the Mexican National Forestry Commission (CONAFOR), pay multistrata agroforestry farmers for ecosystem services provided (e.g., biodiversity protection, hydrological services, and carbon sequestration). The PES may serve the same goal as coffee price premiums in protecting multistrata farms (CONAFOR 2007).

We found that species richness of ants, birds, and trees was negatively affected by coffee- management intensification, and by several vegetation factors relating to intensification. Species richness of ants, birds, and trees was highest in forests and rustic-coffee systems and declined in other coffee-management systems, especially in sun coffee, but forest species of all taxa declined, even in rustic-coffee systems. There were qualitative differences in patterns of species loss depending on the focal taxa, and on functional classifications of birds. Thus, rustic systems likely offer more for biodiversity conservation than other coffee habitats, but intensification of coffee management, when standardized across studies, has different effects on the basis of taxonomic groups examined and their functional traits. We recommend future researchers mention which of the established designated systems most resembles their study sites and provide detailed vegetation data that can be used to independently assess and synthesize data across studies. To develop more synthetic conservation strategies, future studies should address critical relationships between biodiversity, ecosystem services, and farmer livelihoods.

\section{Acknowledgments}

We thank all researchers who contributed data and the reviewers for their helpful comments on the manuscript. R. Chazdon and D. Griffith gave critical support and encouragement for the paper. This work was conducted as a part of the Biodiversity and Conservation Value of Agricultural Landscapes of Mesoamerica Working Group supported by the National Center for Ecological Analysis and Synthesis, a Center funded by National Science Foundation (grant \#DEB-0553768), the University of California, Santa 
Barbara, and the State of California. C. Gordon, C. Tejeda, J. Valenzuela, and G. Williams-Linera acknowledge support of SEMARNAT-202-CO1-00194 and J.V. thanks L. Quiroz for ant identification assistance.

\section{Literature Cited}

Armbrecht, I., L. Rivera, and I. Perfecto. 2005. Reduced diversity and complexity in the leaf litter ant assemblage of Colombian coffee plantations. Conservation Biology 19:97-907.

Arnqvist, G., and D. Wooster. 1995. Meta-analysis: synthesizing research findings in ecology and evolution. Trends in Ecology \& Evolution 10:236-240.

Bancroft, B. A., N. J. Baker, and A. R. Blaustein. 2007. Effects of UVB radiation on marine and freshwater organisms: a synthesis through meta-analysis. Ecology Letters 10:332-345.

Begg, C. B., and M. Mazumdar. 1994. Operating characteristic of a rank correlation test for publication bias. Biometrics 50:1088-1101.

Blackman, A., H. Albers, B. Ávalos-Sartorio, and B. Crooks. 2003. Land cover in a managed forest ecosystem: Mexican shade coffee. Discussion paper 03-60. Resources for the Future, Washington, D.C.

Colwell, R. K. 2005. EstimateS: statistical estimation of species richness and shared species from samples. Version 7.5. University of Connecticut, Storrs, Connecticut. Available from http://purl.oclc.org/estimates (accessed May 2005).

CONAFOR (Comisión Nacional Forestal de México). 2007. Acuerdo por el que se expiden las Reglas de Operación del Programa Pro-Árbol de la Comisión Nacional Forestal. CONAFOR, Mexico City. Available from http://www.conafor.gob.mx/portal/docs/secciones/apoyosc/ proarbol/Reglas_Operacion_PROARBOL.pdf (accessed May 2007).

Cooper, H., and L. Hedges. 1994. The handbook of research synthesis. Russel Sage Foundation, New York.

Cruz-Angon, A., and R. Greenberg. 2005. Are epiphytes important for birds in coffee plantations? An experimental assessment. Journal of Applied Ecology 42:150-159

Fisher, R. 1928. Statistical methods for research workers. Oliver and Boyd, London.

Gordon, C., R. Manson, J. Sundberg, and A. Cruz-Angón. 2007. Biodiversity, profitability, and vegetation structure in a Mexican coffee agroecosystem. Agriculture Ecosystems and Environment 118:256266.

Gotelli, N., and R. Colwell. 2001. Quantifying biodiversity: procedures and pitfalls in the measurement and comparison of species richness. Ecology Letters 4:379-391.

Gray, M., S. Baldauf, P. Mayhew, and J. Hill. 2007. The response of avian feeding guilds to tropical forest disturbance. Conservation Biology 21:133-141.

Greenberg, R., P. Bichier, and J. Sterling. 1997. Bird populations in rustic and planted shade coffee plantations of eastern Chiapas, Mexico. Biotropica 29:501-514.

Johnson, M. 2000. Effects of shade-tree species and crop structure on the winter arthropod and bird communities in a Jamaican shade coffee plantation. Biotropica 32:133-145.

Jones, D., and A. Hansen. 2006. Avian Communities of the middle and lower Yellowstone River: a pilot study. Final pilot report. The Nature Conservancy, Arlington, Virginia.

Klein, A., I. Steffan-Dewenter, D. Buchori, and T. Tscharntke. 2002. Effects of land-use intensity in tropical agroforestry systems on coffee flower-visiting and trap nesting bees and wasps. Conservation Biology 16:1003-1014.

Komar, O. 2006. Ecology and conservation of birds in coffee plantations: a critical review. Bird Conservation International 16:1-23.

Langellotto, G., and R. Denno. 2004. Responses of invertebrate natural enemies to complex-structured habitats: a meta-analytical synthesis. Oecologia 139:1-10.
Mas, A., and T. Dietsch. 2003. An index of management intensity for coffee agroecosystems to evaluate butterfly species richness. Ecological Applications 13:1491-1501.

Moguel, P., and V. Toledo. 1999. Biodiversity conservation in traditional coffee systems of Mexico. Conservation Biology 13:11-21.

Perfecto, I., A. Mas, T. Dietsch, and J. Vandermeer. 2003. Conservation of biodiversity in coffee agroecosystems: a tri-taxa comparison in southern Mexico. Biodiversity and Conservation 12:1239-1252.

Perfecto, I., R. Rice, R. Greenberg, and M. VanderVoort. 1996. Shade coffee: a disappearing refuge for biodiversity. BioScience 46:598608.

Perfecto, I., and J. Vandermeer. 2002. The quality of agroecological matrix in a tropical montane landscape: ants in coffee plantations in southern Mexico. Conservation Biology 16:174-182.

Perfecto, I., J. H. Vandermeer, G. L. Bautista, G. I. Nunez, R. Greenberg, P. Bichier, and S. Langridge. 2004. Greater predation in shaded coffee farms: the role of resident Neotropical birds. Ecology 85:26772681.

Philpott, S. 2007. Ants, birds, and tree diversity: coffee agroecosystem meta-analysis. National Center for Ecological Analysis and Synthesis, Santa Barbara, California. Available from http://knb.ecoinformatics. org/knb/metacat/nceas.338.11/nceas (accessed September 2007).

Philpott, S., and I. Armbrecht. 2006. Biodiversity in tropical agroforests and the ecological role of ants and ant diversity in predatory function. Ecological Entomology 31:369-377.

Pineda, E., C. Moreno, F. Escobar, and G. Halffter. 2005. Frog, bat and dung beetle diversity in the cloud forest and coffee agroecosystems of Veracruz, Mexico. Conservation Biology 19:400-410.

Pinkus-Rendon, M. A., J. L. Leon-Cortes, and G. Ibarra-Nunez. 2006. Spider diversity in a tropical habitat gradient in Chiapas, Mexico. Diversity and Distributions 12:61-69.

Ramos, M., H. Morales, L. Ruiz-Montoya, L. Soto-Pinto, and P. RojasFernández. 2002. ¿Se mantiene la diversidad de hormigas con el cambio de bosque mesófilo a cafetales? Pages $16-30$ in A. Monro and M. Peña, editors. Special edition, Año 12. Revista Protección Vegetal San Salvador, El Salvador.

Rappole, J. H., D. I. King, and J. H. V. Rivera. 2003. Coffee and conservation. Conservation Biology 17:334-336.

Ricketts, T., G. Daily, P. Ehrlich, and J. Fay. 2001. Countryside biogeography of moths in a fragmented landscape: biodiversity in native and agricultural habitats. Conservation Biology 15:378-388.

Romero-Alvarado Y., L. Soto-Pinto, L. García-Barrios, and J. F. BarreraGaytán. 2002. Coffee yields and soil nutrients under the shade of Inga sp. vs. multiple species in Chiapas, Mexico. Agroforestry Systems 54:215-224.

Rosenberg, M. S. 2005. The file-drawer problem revisited: a general weighted method for calculating fail-safe numbers in meta-analysis. Evolution 59:464-486.

Rosenberg, M. S., D. C. Adams, and J. Gurevitch. 2000. Metawin: statistical software for meta-analysis, version 2. Sinauer Associates, Sunderland, Massachusetts.

Rosenthal, R. 1979. The "file drawer problem" and tolerance for null results. Psychological Bulletin 86:638-641.

Sabo, S., and R. Holmes. 1983. Foraging niches and the structure of forest bird communities in contrasting montane habitats. Condor 85:121-138.

Sokal, R., and F. Rohlf. 1995. Biometry. Freeman, San Francisco.

Soto-Pinto, L., I. Perfecto, J. Castillo-Hernández, and J. Caballero-Nieto. 2000. Shade effect on coffee production at the northern Tzeltal zone of the state of Chiapas, Mexico. Agriculture Ecosystems and Environment 80:61-69.

Steffan-Dewenter, I. 2002. Landscape context affects trap-nesting bees, wasps, and their natural enemies. Ecological Entomology 27:631637.

Steffan-Dewenter, I. et al. 2007. Tradeoffs between income, biodiversity, and ecosystem functioning during tropical rainforest 
conversion and agroforestry intensification. Proceedings of the National Academy of Sciences of the United States of America 104:4973-4978.

Stotz, D., J. Fitzpatrick, T. Parker III, and D. Moskovits. 1996. Neotropical birds: ecology and conservation. The University of Chicago Press, Chicago, Illinois.

Tejeda-Cruz, C., and C. Gordon. 2008. Aves. Pages 149-161 in R. H. Manson, V. Hernández, S. Gallina, and K. Mehltreter, editors. Agroecosistemas cafeteleros de Veracruz: biodiversidad, manejo y conservación. INE-INECOL, México, D.F.

Tejeda-Cruz, C., and W. J. Sutherland. 2004. Bird responses to shade coffee production. Animal Conservation 7:169-179.
Toledo, V. M., and P. Moguel. 1996. En Busca de un café sostenible en México: la importancia de la diversidad biológica y cultural. Congreso del Café Sostenible (1). Smithsonian Migratory Bird Center, Washington D.C.

Vandermeer, J., and R. Carvajal. 2001. Metapopulation dynamics and the quality of the matrix. The American Naturalist 159:211-220.

Vandermeer, J., and I. Perfecto. 2007. The agricultural matrix and a future paradigm for conservation. Conservation Biology 21:274277.

Wunderle, J. Jr. 1999. Avian distribution in Dominican shade coffee plantations: area and habitat relationships. Journal of Field Ornithology 70:58-70.

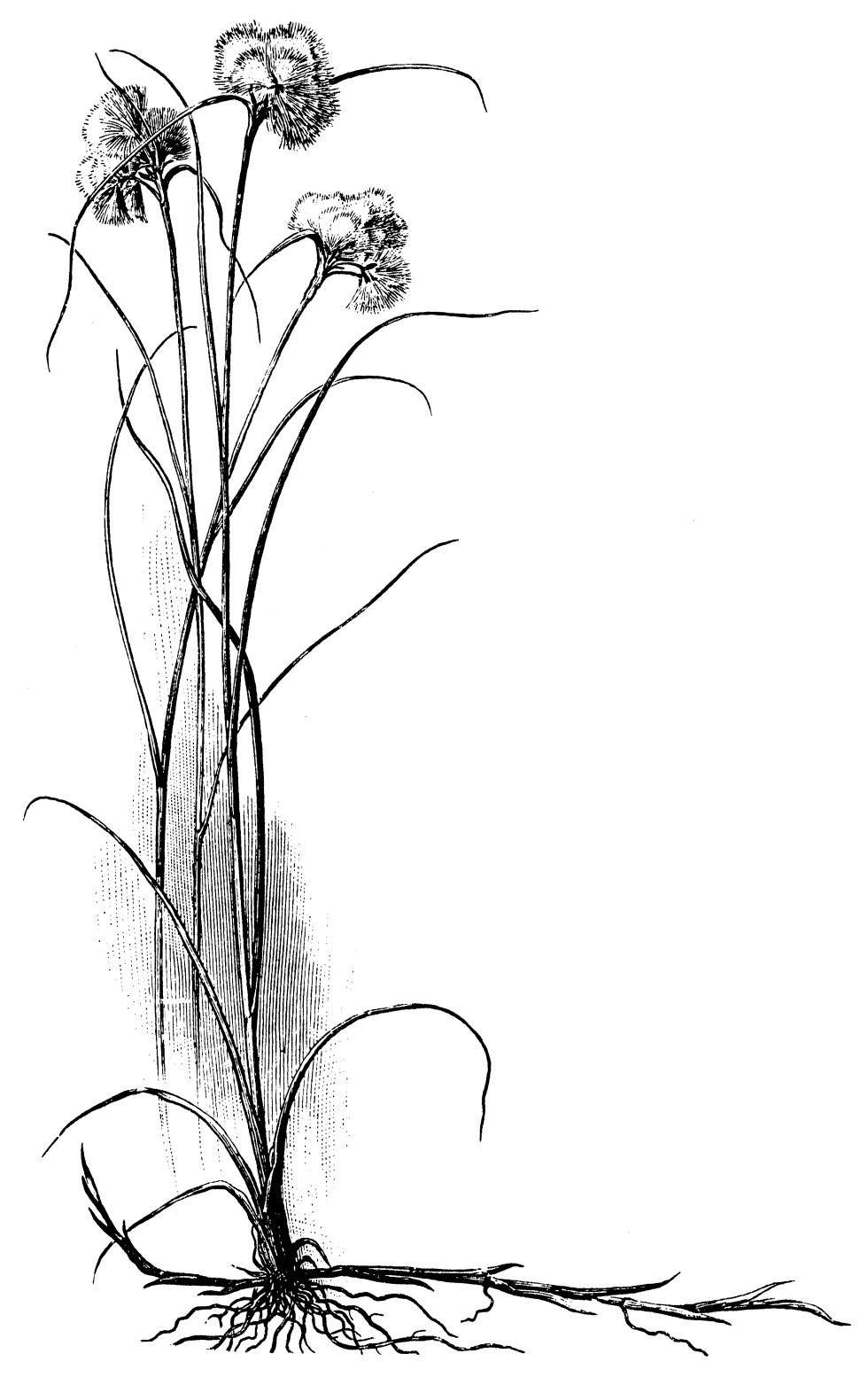

